This is the authors' final version of the paper published in The Service Industries Journal Original publication available at:

https://www.tandfonline.com/doi/full/10.1080/02642069.2018.1508458

You can cite this paper as:

Femenia-Serra, F., Neuhofer, B., \& Ivars-Baidal, J. A. (2018). Towards a conceptualisation of smart tourists and their role within the smart destination scenario. The Service Industries Journal, (forthcoming). https://doi.org/10.1080/02642069.2018.1508458

\title{
Towards a conceptualisation of smart tourists and their role within the smart destination scenario
}

\section{智慧型旅游者概念化及其在智慧目的地场景中的角色}

Francisco Femenia-Serra $^{\mathrm{a} *}$, Barbara Neuhofer ${ }^{\mathrm{b}}$, Josep A. Ivars-Baidal $^{\mathrm{a}}$

${ }^{a}$ Tourism Research Institute, University of Alicante, Campus Sant Vicent del Raspeig, 03080 Alicante, Spain

${ }^{\mathrm{b}}$ Department of Innovation and Management in Tourism, Salzburg University of Applied Sciences, Campus Urstein Süd 1, 5412 Puch-Salzburg, Austria

*Corresponding author. Tel.: +34 965903400(3726); fax: +34 965909552

Email addresses: paco.femenia@ua.es (F. Femenia-Serra), barbara.neuhofer@fh-salzburg.ac.at (B. Neuhofer), josep.ivars@ua.es (J.A. Ivars-Baidal)

Abstract: 'Smart tourism' and 'smart destinations' have been gaining attention as new frameworks within which to understand the impact the latest information and communication technologies (ICTs) have on the relationship between businesses, destinations and tourists. However, there is a crucial element of the smart tourism ecosystem that has been rather neglected in research hitherto: the tourists themselves. By acknowledging a shift 
in tourists' behaviour due to the advent of disruptive factors, this paper conceptualises the recently emerged notion of 'the smart tourist'. This new type of tourist is profiled through a description of their attitudes and behaviours, and their role within the smart destination scenario is depicted. By taking a consumer-centric perspective and framing the conceptualisation within the relevant theories, this paper contributes to the current body of knowledge on tourism in a highly technological context and facilitates bridging smart tourism theoretical foundations with empirical research. The observed transformation in tourists' behaviour and its encapsulation in the smart tourist conceptualisation reveal critical managerial implications for both destination management organisations and businesses in the rapidly changing smart tourism ecosystem.

Keywords: Smart tourism; Smart tourism destination; ICTs; Tourist behaviour; Smart tourist

摘要: “智慧旅游” 和 “智慧目的地” 作为一个可以了解最新信息和通信技术 (ICT) 对企业, 目的地和 旅游者之间的关系影响的新框架越来越受到人们的关注。然而, 智慧旅游生态系统的一个关键因素一直 以来都被忽视: 旅游者自身。通过承认由于破坏性因素的出现导致游客行为的转变, 本文对最近出现的 “智慧型旅游者” 观念进行了概念化。通过对其的态度和行为的描述, 本文描绘了这种新型旅游者及他 们在智慧目的地情景中的角色。本文以消费者为中心的观点, 在相关理论的框架下为当前的旅游知识体 系做出了贡献, 并为智慧旅游的理论基础与实证研究打下了坚实的基础。观察到的游客行为转变及其在 智慧旅游概念化中的封装揭示了在快速变化的智慧旅游生态系统中目的地管理组织和企业的重要管理意 义。

关键词 : 智慧旅游; 智慧目的地; 信息通信技术; 旅游行为; 智慧型旅游者

\section{Introduction}

Since the 1990s, the constant progress in the development of ICTs has induced significant transformations in tourist behaviour, leading to a tourist who is informed, empowered and wishes to obtain more personalised and better-designed experiences (Buhalis \& Foerste, 2015; Buhalis \& Law, 2008; Gretzel, Fesenmaier, \& O’Leary, 2006). In this context, the crucial interplay of multiple forms of ICTs have made it possible for service providers to cocreate together with customers, who now get tailored and richer experiences (Binkhorst \& Dekker, 2009; Prahalad \& Ramaswamy, 2004b). This has meant a structural change for tourist experiences, as they have been partly mediated and reshaped by new technologies (Neuhofer, Buhalis, \& Ladkin, 2012; Tussyadiah \& Fesenmaier, 2009; D. Wang, Park, \& Fesenmaier, 2012; D. Wang, Xiang \& Fesenmaier, 2016). Nevertheless, not only tourists and their experiences are facing vital changes, but also destinations. ICTs have given rise to 
multiple opportunities for destinations to improve their performance and processes (Buhalis, 2003), but at the same time, they challenge the traditional structures. New innovations and tools are emerging at an increasingly faster pace, making it difficult for destinations to keep up to date in the context of global competition. Destinations need to adapt themselves to this new situation, and destination management organisations (DMOs) play a critical role in managing these shifts and ensuring the required strong performance and collaboration among all the stakeholders to do so (Bornhorst, Ritchie, \& Sheehan, 2010; d'Angella \& Go, 2009).

This rapid evolution of ICTs means that tourism, destinations, tourists and experiences can no longer be considered in the same way as before. Cutting-edge technological developments, such as intelligent systems, the Internet of Things (IoT) or cloud computing, are all reshaping these concepts and forcing to take a step further and develop new viable models for an unprecedented situation for destinations and tourists alike (Lamsfus, Martín, Alzua-Sorzabal, \& Torres-Manzanera, 2015; Xiang \& Fesenmaier, 2017). In this context, smart destinations (SDs) have recently emerged as a plausible response to these structural changes, seizing the opportunity to provide enhanced and more personalised experiences through higher levels of interconnection among stakeholders in the smart service system (Buhalis \& Amaranggana, 2014, 2015; Buonincontri \& Micera, 2016).

While research on smart tourism and smart destinations is still emerging (Del Chiappa \& Baggio, 2015; Jovicic, 2017), it has attracted great attention, even with the publication of some special issues devoted to the topic (e.g. Koo, Park, \& Lee, 2017; Koo, Yoo, Lee, \& Zanker, 2016; Xiang et al., 2015). However, there are many subtopics within the field still to be addressed, such as the general lack of knowledge about tourists as human actors and their role in this setting (Xiang \& Fesenmaier, 2017). It remains unknown: $a$ ) how tourists understand intelligent systems and wish to interact with them (Gretzel, 2011), b) how they perceive ICTs regarding the enhancement of their experiences (Buonincontri \& Micera, 2016), c) how specifically they are supposed to interact and co-create with other stakeholders (Gretzel, Werthner, Koo, \& Lamsfus, 2015), and $d$ ) how their level of trust in technologies shapes and facilitates the task and intervenes in their experiences (Gretzel, Sigala, Xiang, \& Koo, 2015; Gretzel, Werthner, et al., 2015).

In a nutshell, it appears that there is a critical lack of 1) conceptual schemes that characterise tourists in this context and their complex role within SDs, and 2) empirical research from an emic perspective putting tourists' needs and preferences within smart tourism at the centre. This paper seeks to fill the first of these gaps, and therefore its objective is to establish the 
attributes of the type of tourist who fits into the smart destination scenario by further conceptualising a novel and under-researched concept hitherto: 'the smart tourist', including their characteristics and their role within the SD. Despite the notable research gaps, emerging evidence show 'traces' of tourists who already meet some of the anticipated attributes in this context and open the possibility to consider a new type of tourist not deeply defined yet (the smart tourist), who could be present within different demand segments and in different degrees.

Two clarifications are needed at this point. First, this conceptualisation is attempted while acknowledging that within postmodern research it is recognised that tourists and their behaviour are diverse by nature, and so are their experiences, and the ways that these socially constructed concepts can be understood (McCabe, 2005). This diversity has led to many studies that define typologies of tourists, which consider motivations, socioeconomic characteristics, decision making and activities or views of host communities, perusal of certain values and psychographic characteristics, as the seminal studies of Cohen (1972, 1974) reflect. It is beyond the scope of this paper to create a definitive, full new typology of smart tourists, or to define a completely distinguishable and closed market segment. Rather, the objective is to establish the underlying attitudes and behaviours of tourists who fit into the smart destination scenario, focusing on ICTs as the critical element to profile these smart tourists. Furthermore, the presented conceptual model is descriptive and does not intend to be quantitatively tested as it is, but rather to serve as inspiration for future empirical exploration. Second, this conceptualisation is partially grounded on the principles of 'conceptual research' (Xin, Tribe, \& Chambers, 2013), and thus builds upon existing concepts to further develop a new one and seeks at the same time to foster creative and different perspectives towards some already researched fields (tourist-ICTs relationship, for instance), but providing new foundations according to recently emerged factors and context. In line with this, the definition of emergent types of tourists along with the advent of novel conceptual frameworks is a constant in tourism research: the 'green tourist' (Dolnicar \& Matus, 2008) in relation to ecotourism and sustainability, or the 'creative tourist' (Gretzel \& Jamal, 2009) in relation to creative tourism, are just some recent examples. In this vein, this paper argues we are in front of the progressive construction of a 'smart tourist' within the smart tourism paradigm and that this needs to be properly defined for a better management of destinations and experience facilitation in the smart service ecosystem. This way, this article extends current understanding around tourism demand in a highly technological context by 
introducing an original approach which enriches the theoretical foundations of smart tourism and renders new possibilities for its future empirical enquiry.

The paper is organised as follows. First, it develops a general context and a robust theoretical background, describing the evolution from 'eTourism' and 'eDestinations' to the new 'Smart Tourism' and 'Smart tourism destinations'. Second, it identifies and discusses literaturebased critical factors representative of the inter-relationship between tourists and technology within SDs, namely tourists' (i) privacy and security concerns regarding data sharing, (ii) acceptance and use of smart technologies and (iii) perception of interaction and co-creation with stakeholders through smart technologies. These three critical factors emerged as the basis for capturing the concept of the smart tourist. The smart tourist is defined, developed, modelled, and underpinned with different evidence (secondary data, cases of best practices) which support its relevance. This is followed by a model that depicts the tourist's role within the wider SD. Finally, the theoretical contributions and managerial implications are discussed, together with the study limitations and suggestions for future research.

\section{Theoretical Background}

\section{From eTourism to Smart Tourism}

The development of intelligent systems and technologies has fostered the appearance of smart tourism, a buzzword and trending topic (Park, Lee, Yoo, \& Nam, 2016; X. Wang, Li, Zhen, \& Zhang, 2016). Smart tourism may be understood as an evolution, a step forward of eTourism (Gretzel, Sigala, et al., 2015; Xiang \& Fesenmaier, 2017). While eTourism refers to the utilisation of ICTs in the processes carried out by tourism organisations and among many players for improving business strategy and organisational performance (Buhalis, 2003), smart tourism is distinguished for fusing the physical world to the digital sphere through the use of the Internet of Things (IoT) and Ambient Intelligence (AI). Smart tourism also encompasses the transformation that experiences have undergone in recent years, and the widespread availability of ubiquitous connectivity (Gretzel, Reino, Kopera, \& Koo, 2015; Gretzel, Sigala, et al., 2015). This means a new stage in the impact ICTs have on tourism, consisting in 'the integrated efforts at a destination to collect and aggregate/harness data derived from physical infrastructure, social connections, government/organizational sources and human bodies/minds in combination with the use of advanced technologies to transform that data into on-site experiences and business value-propositions with a clear focus on efficiency, sustainability and experience enrichment' (Gretzel, Sigala, et al., 2015, p.181). 
Moreover, smart tourism can be understood as an 'ecosystem', constituted by a smart business network, smart destinations and a smart technologies infrastructure (Gretzel, Reino, Kopera, \& Koo,2015). Besides, Gretzel, Werthner, Koo, \& Lamsfus (2015) establish that in this smart tourism ecosystem there is a symbiotic relationship among the species, resulting in benefits for the whole system, and for each individual.

Irrespective of the context of smartness and its actors or 'species', one concern always remains the same: to provide tourists with higher satisfaction, improved experiences and a better achievement of their individual preferences (Liberato, Alen, \& Liberato, 2018; X. Wang et al., 2016), through varied 'smart solutions' (Ivars-Baidal, Celdrán-Bernabeu, Mazón, \& Perles-Ivars, 2017). Gretzel (2011) argues that intelligent systems can provide better tourist experiences thanks to a superior management of information and a higher support in decision making. They offer flexibility and adaptability to the context and have the capacity to learn from experience and provide feedback accordingly. Acknowledging all this potential, smartness is increasingly included in the analysis of destinations, in their planning and management processes as well as in their relationship with tourists. This growing interest is evident in the great attention smart destinations are receiving in countries such as China (Li, Hu, Huang, \& Duan, 2016; Ryan et al., 2016; D. Wang, Li, \& Li, 2013), South Korea (Koo, Shin, Kim, Kim, \& Chung, 2013; Park, Lee, Yoo, \& Nam, 2016) or Spain (IvarsBaidal et al., 2017; López de Ávila \& García, 2013).

\section{From the eDestination to the Smart Destination}

It is precisely the smart tourism destination (SD) concept that is attracting most attention in research, and could even be considered as a relevant recent evolution of the 'destination' concept (Jovicic, 2017). However, its theoretical development is still limited and the destination notion itself is deemed as a complex, changing, socially-constructed and multilayered reality, as reflected in recent literature (e.g. Pearce, 2014; Saarinen, 2004; Saraniemi \& Kylänen, 2011, etc.).

Smart destinations have been inspired by some prior conceptualisations, such as 'eDestinations'. Nevertheless, while eDestinations emphasised the utilisation of ICTs to provide information and to become an instrumental part of all transactions (Buhalis, 2003), in smart destinations technology is centrally embedded in all elements thanks to new developments, such as the Internet of Things (Koo et al., 2016). Technology here becomes the space, where all the interconnections among stakeholders happen (Gretzel, Werthner, et 
al., 2015). To date, there is no general agreement on a definition for smart tourism destinations (Del Chiappa \& Baggio, 2015), but one of the most commonly used is provided by the Spanish innovation fostering institution SEGITTUR together with the country's standardisation agency AENOR. According to these organisations, a SD is 'An innovative tourist area, accessible to everyone, and built on a state-of-the-art technological infrastructure, which guarantees a sustainable development of territory, facilitates the interaction of visitors and their integration in their surroundings and enhances the quality of their experiences at destinations and the residents' quality of life' (SEGITTUR, 2015, p.32). But many other definitions of SDs have emerged (see for instance: Del Chiappa \& Baggio (2015); Lamsfus et al. (2015) or Micera, Presenza, Splendiani \& Del Chiappa (2013)).

SDs should aim to improve tourist experiences, for which integrating ICTs into the physical world is crucial. This is in line with Boes et al. (2015), who consider SDs as those places that employ ICTs for enhancing tourist experiences and the performance of organisations through a greater, jointly provided, co-creation of value. Therefore, improving tourist experiences through the use of the latest ICTs and smart services is the core objective of SDs. This could be achieved, theoretically, through a central technological platform that could interconnect all the stakeholders, integrate the data input from different sources, and allow for dynamic, realtime information sharing. This would maximise efficiency, improve decision making and enhance tourist experiences (Buhalis \& Amaranggana, 2014; Choe \& Fesenmaier, 2017; X. Wang et al., 2016; Xiang et al., 2015) in a context in which destinations need to remain competitive and innovate more than ever before by promoting stronger ties and an intelligent sharing of knowledge among stakeholders (Baggio \& Cooper, 2010).

Still, in SDs general technological advancements need to be adapted to concrete smart technologies (STs), which are specific tools created for determined purposes that in the field of tourism add value by fostering a higher interaction, co-creation and personalisation of experiences (Neuhofer, Buhalis, \& Ladkin, 2015). These technologies have superior capacities, allow higher levels of interconnection and constantly create data which is accessible to take informed decisions (Gretzel, Werthner, et al., 2015). STs are therefore a crucial element for the development of better experiences in SDs (Buonincontri \& Micera, 2016), as the possibilities they offer in terms of greater personalisation and dynamic real-time co-creation can give rise to smart experiences (Gretzel, Sigala, et al., 2015). 


\section{From the Digital Tourist to the Smart Tourist: Identifying Critical Factors}

Apart from destinations, tourists themselves have undergone a great transformation because of the irruption of new technologies. The 'tourist' construct occupies a central position in research and has traditionally attracted great attention together with the 'tourist experience' associated concept, as reflected in many seminal articles (e.g. E. Cohen, 1974, 1979; MacCannell, 1976; Turner \& Ash, 1975), but also in more recent research (McCabe, 2005; Uriely, 2005; Urry \& Larsen, 2011; Wickens, 2002). This interest has been lately fostered by the emergence of new ICTs and their impact on tourist behaviour (S. Cohen, Prayag, \& Moital, 2014; Gretzel, Fesenmaier, \& O’Leary, 2006) and experiences (Neuhofer et al., 2012).

At the turn of the last century, tourists formed part of a major transformation in the information search, booking, personalisation and communication processes due to the use of innovative technologies (Buhalis, 2001). In the last decade, these changes have evolved even faster with the rapid emergence of user-generated online content (Tussyadiah \& Fesenmaier, 2009), the rise of smartphones (D. Wang et al., 2012; 2016), social media (Munar \& Jacobsen, 2014), context and location-aware services (Buhalis \& Foerste, 2015), and the impact of them on experiences. Tourists have become more demanding, active, independent, informed and skilled, and have discovered new ways of searching for information, comparing, booking, interacting, sharing, complaining, reviewing and recommending (Buhalis, 2003; Buhalis \& Law, 2008). The implications of these changes have been vast and have shaped a digital tourist (Benckendorff, Sheldon, \& Fesenmaier, 2014; Pearce, 2011). However, the expansion of the IoT, ubiquitous connectedness, the mass generation of big data and the widespread adoption of mobile devices, and most of all, what these technologies require from the user and what is anticipated from them, call for an updated framework to better understand the tourist in this smart scenario. The existing conceptualisations do not seem enough to capture the new era in the relationship between tourists, ICTs and destinations. Single technologies adoption studies and current conceptual frameworks for tourists-ICTs interplay have been rendered partially obsolete because of the factors cuttingedge technologies have introduced, such as real-time interaction and ubiquitous connectedness (Neuhofer et al., 2015), new types of technology-mediated social connections, or superior levels of context-awareness (Buhalis \& Foerste, 2015).

While there is increasing evidence of an emergent stage in the attitudes and behaviours of tourists who are adapting to these technologies and ecosystem, these have been to date 
disaggregated pieces of a missing scheme to interpret them properly. The 'smart tourist' construct could serve to capture this shift, as for the moment no systematic attempt has been made to define tourists' position within the smart destination and only minor references to 'smart tourists' have been made until now (e.g. Gretzel, Reino, et al., 2015; Gretzel, Sigala, et al., 2015). In short, there is a quest to understand who exactly the smart tourist is and which implications its advent has on a theoretical and managerial levels.

With the purpose of addressing this need, a thorough review of the current literature on smart tourism destinations, technology and tourist behaviour, and their interplay with the broader smart tourism paradigm was performed, seeking to identify the gaps in the relationship between the tourist and the smart destination. The critical revision of the existing literature has given rise to the identification of key, but under-researched factors that are central for the conceptualisation of smart tourists and their role within SDs:

Table 1. Identification of under-researched technological factors shaping tourists in the smart destination

\begin{tabular}{l|l}
\hline \multicolumn{1}{c|}{ Critical factors } & \multicolumn{1}{c}{ Evidence in literature } \\
$\begin{array}{l}\text { 1) Privacy and security concerns } \\
\text { regarding data sharing }\end{array}$ & $\begin{array}{l}\text { Buhalis \& Amaranggana, 2014, 2015; González-Reverté et al., 2018; } \\
\text { Gretzel, Reino, et al., 2015; Gretzel, Sigala, et al., 2015; Gretzel, } \\
\text { Werthner, et al., 2015; Huang, Goo, Nam, \& Yoo, 2017; Xiang \& } \\
\text { Fesenmaier, 2017 }\end{array}$ \\
$\begin{array}{l}\text { 2) Acceptance and use of smart } \\
\text { technologies }\end{array}$ & $\begin{array}{l}\text { Buonincontri \& Micera, 2016; González-Reverté et al., 2018; Gretzel, } \\
\text { 2011; Gretzel, Reino, et al., 2015; Gretzel, Sigala, et al., 2015; Gretzel, } \\
\text { Werthner, et al., 2015; Liberato, et al., 2018 }\end{array}$ \\
$\begin{array}{l}\text { 3) Perception of interaction and co- } \\
\text { creation with stakeholders through } \\
\text { smart technologies }\end{array}$ & $\begin{array}{l}\text { Boes et al., 2015, 2016; Buhalis \& Amaranggana, 2014, 2015; } \\
\text { Buonincontri \& Micera, 2016; Choe \& Fesenmaier, 2017; Gretzel, }\end{array}$ \\
\hline
\end{tabular}

Although it is acknowledged that other factors may be influential, they have been discarded for not being exclusively related to the smart paradigm and for not implying distinctive, unique tourist attitudes and behaviours other than those required in non-smart contexts, where technology does not play such a prominent role. Next, each of these elements is explored and framed within its relevant theoretical framework. 


\section{Tourists' Privacy and Security Concerns regarding Data Sharing}

One of the unique features of SDs is their capacity to offer experiences tailored to tourists' preferences, due to the access, gathering and exploitation of their data, which allows the creation of patterns and facilitates the prediction of future needs and improvement of services (Buhalis \& Amaranggana, 2015). While some experience personalisation degree through technologies is possible without accessing tourists' data, most of the advanced smart services and experience creation processes require these data to gain better insights into the tourist. A complete data sharing for a higher personalisation of experiences would entangle from basic information (e.g. age, sex, nationality, etc.) to more specific and personal data (e.g. real-time position, expenses, profiles on social media, etc.) (Buhalis \& Amaranggana, 2015; Buhalis \& Foerste, 2015). However, this can rise privacy and security concerns among tourists in the context of smart destinations (González-Reverté, Díaz-Luque, Gomis-López, \& MoralesPérez, 2018).

Concerns about privacy and personal security have been proved to be a main issue in the current digital tourism ecosystem (Buhalis \& Law, 2008). Research on privacy and security is still lagging behind, but is increasingly becoming a driving topic in tourism research (e.g. Brown, Muchira, \& Gottlieb, 2007; Lee \& Cranage, 2011; Saravanan \& Ramakrishnan, 2016), and can be combined with other constructs to form the 'trust' and 'perceived risk' elements (Kim, Ferrin, \& Rao, 2008). Identifying these privacy and security concerns is key to minimising the impact and involving tourists. In the late 1990s, Smith, Milberg, \& Burke (1996) developed a theory and an instrument that measured consumer concerns regarding information privacy treatment by organisations in five categories: 1) extensive collection of identifiable data; 2) internal unauthorised use of secondary data; 3) external unauthorised use of secondary data; 4) improper access by unauthorised individuals; 5) errors in data managing, both deliberate and accidental. This theory has been partially applied in relation to the purchase of travel services (Brown et al., 2007), although other studies have employed different models for studying privacy and security concerns within trust, in combination with other constructs (e.g. Bonsón Ponte et al., 2015), and could be partially adopted for smart tourism. Together with the concerns detected by Smith et al. (1996), some more specific perils arise in the smart tourism paradigm for the tourist, including the hacking of the central intelligence system, movement monitoring, abusive marketing by companies, or even blackmailing or stalking of tourists (Saravanan \& Ramakrishnan, 2016). A reality which is markedly relevant for privacy in the smart context is the growing use of location-based 
services (LBS). LBS are ICT-based services that use geographical location to provide users with position-aware information and navigation options and can be particularly powerful in combination with mobile technologies and social media (Buhalis \& Foerste, 2015). However, LBS raise strong privacy concerns among users because of the perceived relevance of location information, which is seen as highly sensitive private data, and can influence the predisposition to use certain LBS (Anuar \& Gretzel, 2011). The relevance of mobile technologies in smart destinations and the utilisation of users' location by many mobile apps make this issue very significant.

However, the whole smart tourism idea relies greatly on the assumption that tourists are open to sharing their data in order to obtain better services and experiences (Gretzel, Reino, et al., 2015). Destinations have largely taken the predisposition of tourists to provide all information for granted because they are supposedly looking for tailored experiences (Gretzel, Sigala, et al., 2015). The perception of tourists around these issues shape their behaviour, but a second major factor further influences it: the degree of acceptance and use of smart technologies. Therefore, if privacy and security concerns are overcome, this could explain, just partly and together with other factors, the move of the tourist towards the second step: accepting and using smart technologies.

\section{Acceptance and Use of Smart Technologies}

Smart technologies (STs) figure prominently in current smart tourism panorama, due to their capacity to provide rich information and higher efficiency (Huang et al., 2017), and most importantly, to offer an experience personalisation and co-creation through ubiquitous connectivity (Neuhofer et al., 2015). Smart technologies can create new levels of humanmachine interaction, using different devices and updated information, that may transform experiences and businesses (Gretzel, Zhong, \& Koo, 2016).

The range of existing smart technologies is overwhelming. The term can refer to fairly generalist concepts, or specific applications that enhance experiences and add value in a concrete manner (Neuhofer et al., 2015). A rather comprehensive list of general and specific smart technologies includes: ambient intelligence, ubiquitous computing and IoT (three interrelated general concepts), big data and its mining, cloud computing, ubiquitous connectivity through Wi-Fi and other networks, Near Field Communication (NFC) and Radio-Frequency-Identification (RFID), sensors, smartphones and other mobile connected devices, beacons, virtual and augmented reality, mobile apps, integrated payment methods, 
smart cards, last generation websites and social networks sites, etc. (Buonincontri \& Micera, 2016; Gretzel, Reino, et al., 2015; Gretzel, Zhong, \& Koo, 2016; Huang et al., 2017; D. Wang, Li \& Li, 2013). Among these, smartphones are crucial for acting as the main interface between the user and the rest of the stakeholders at the SD, but also because of the possibilities these smart devices offer in terms of personalisation, context-awareness and realtime interaction (Choe \& Fesenmaier, 2017). For this and because of their massive adoption by users, smartphones must be considered the base on which many other technologies need to rely on for their functioning.

In a nutshell, all these smart technologies play a critical role within the smart tourism system for experience co-creation and mediation, and therefore capturing tourists' level of acceptance and use of these STs is crucial (Liberato et al., 2018). However, technologies acceptance and use face a complex and diverse reality. As Gretzel, Reino et al. (2015) argue, the technological gap or divide constitutes a notable barrier, and smart destinations may need to recognise different levels of ability and willingness to use technologies, but also the potential negative effects of such an intensive use of ICTs on tourists and their experiences. In line with this, these authors stress the possible counterproductive results of a technologybased experience, such as information overload, excessive cognitive effort or loss of authenticity.

To examine these and other aspects, many theories for the acceptance and use of technologies exist, some of which have been applied in tourism research. The Technology Acceptance Model (TAM) (Davis, 1989; Davis, Bagozzi, \& Warshaw, 1989), for instance, has been widely used in the context of tourism (e.g. Luque-Martínez, Alberto Castañeda-García, FríasJamilena, Muñoz-Leiva, \& Rodríguez-Molina, 2007). This theory is followed in popularity by the holistic Unified Theory of Acceptance and Use of Technology (UTAUT) (Venkatesh, Morris, Davis, \& Davis, 2003) and the evolved UTAUT II (Venkatesh, Thong, \& Xu, 2012). An application of a model for the acceptance and use of technology in the smart tourism paradigm could illuminate this scope. Once smart technologies are accepted, if this is the case, the willingness of the tourist to use them for interacting and dynamically co-creating with other stakeholders in the SDs becomes the third and final determining factor that shapes the smart tourist.

Perception of interaction and co-creation with stakeholders through smart technologies 
Stakeholders' importance in smart destination is well known, but not new. Stakeholders are the pillars of any destination and a strong collaboration among them is crucial for success (Bornhorst et al., 2010). According to their importance, the stakeholder theory, first developed by R.E. Freeman for the organisational context in the 1980s, advocates an equal treatment of all the stakeholders within an organisation, defends joint decision making, and suggests considering all the parts that have an influence in the organisation's functioning (Sautter \& Leisen, 1999). This way, this theory seems aligned with part of the principles of the smart tourism and destinations. Furthermore, smart destinations constitute an appropriate response to the needs detected by d'Angella \& Go (2009, p.430): "The "fixed-flexible" paradox should give pause to DMOs to reflect on the urgent need to install a platform which enables it and its stakeholders to improve their agility and competitiveness', and also when stating that 'DMO must establish a platform which applies a knowledge-based marketing design that enables it to match the stakeholders' capacity and specific competences to tourists' needs' (p.431). The SDs intelligence platform, interconnecting all stakeholders and facilitating the flow of knowledge, emerges as an opportunity to close these gaps and foster a greater interaction, concurring with the stakeholder theory proposals and the functioning of destinations as complex networks (Baggio \& Cooper, 2010).

As Lamsfus et al. (2015) acknowledge, one of the biggest tasks ahead for smart destinations is the empowerment of stakeholders through the creation of a technological infrastructure which supports increased communication and collaboration. An advanced ICT infrastructure enables a more dynamic, less rigid, and fast interaction within organisations and between organisations at the tourist destination. Thus, smart technologies are capable of creating the required solid while flexible links among the agents and result in improved experiences (Gretzel, Werthner, et al., 2015), which are delivered through these same smart technologies. These are strong allies of the necessary co-creation in the current services panorama (Binkhorst \& Dekker, 2009; Prahalad \& Ramaswamy, 2004a, 2004b), implying that the future of destinations depends on their capacity to orientate themselves towards co-creating with tourists during all travel phases, while employing the appropriate technological tools (Neuhofer et al., 2012). Tourists' willingness to embrace these actions and to be active and dynamic co-creators engaging with numerous smart stakeholders is therefore a paramount factor.

In line with this complex context, the role of the different stakeholders is becoming blurred partly due to the disruption provoked by new technologies. Non-traditional actors (sharing 
economy and telecommunications companies, social media platforms, etc.) now play a critical role (Gretzel, Werthner, et al., 2015). Besides, tourists take a much more proactive role in some situations to achieve the expected experience, and also use new types of services that have lately appeared under the umbrella of the sharing economy, for instance. This way, it seems that roles are being dynamically interchanged and new relationships will have to be built to allow value co-creation between recently emerged and old producers, consumers and intermediaries (Gretzel, Sigala, et al., 2015).

In summary, the rise of smartness has induced a structural change in different tourism layers (see Figure 1) and has provoked the emergence of critical factors which have a great impact on tourists and their experiences, shaping the smart tourist, which is addressed in detail as follows.

Figure 1. Smart transformation of tourism and emergence of the smart tourist
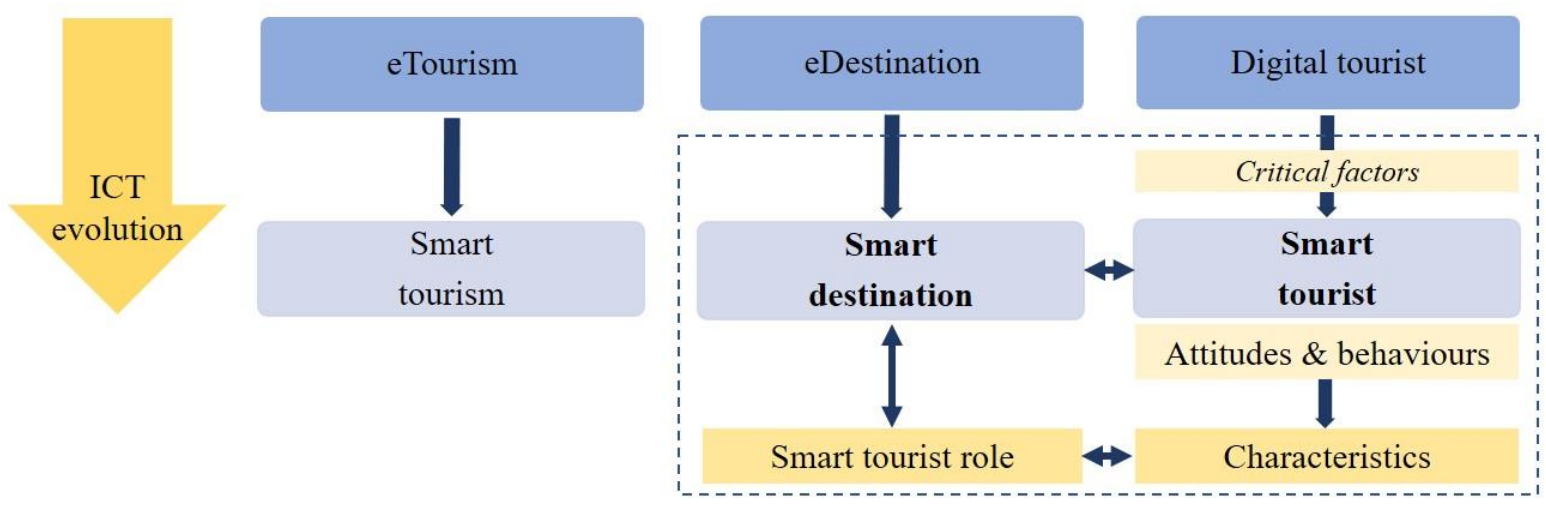

\section{Conceptualising the Smart Tourist and their Role}

Based on the identified technology-related factors influencing the tourist in the wider smart tourism context, this paper proposes a conceptual model for 'the smart tourist'. The main contribution of this conceptualisation is the definition of the characteristics of an emerging kind of tourist in a holistic and structured but open framework, as this conceptualisation also recognises the existing heterogeneity within actual tourists' behaviours.

This way, the smart tourist concept encapsulates the observed shift in recent years in tourists' behaviour and how these behaviours constitute the building blocks for the progressive construction of a smart experience. 


\section{Smart tourist characteristics}

A first step for profiling smart tourists implies outlining their attitudes and behaviours with respect to smart tourism, its functioning and offering. According to Ajzen \& Fishbein (1977), an attitude is an individual's evaluation of 'some aspect of the individual's world, such as another person, a physical object, a behaviour, or a policy' (p.889), while behaviour is understood as 'the observable actions performed by the individual' (p.889). As Venkatesh et al. (2003) recognise, there are contradicting results for the relationship between attitudes, behavioural intention and actual behaviours, but it is also here assumed that a characterisation of a type of tourist is mainly based on the description of these attitudes and behaviours and a certain degree of connection, independently of the causality relationship between them. As shown in the model (Figure 2), it is argued that three characteristic behaviours and related attitudes define who the smart tourist is:

Figure 2. The smart tourist

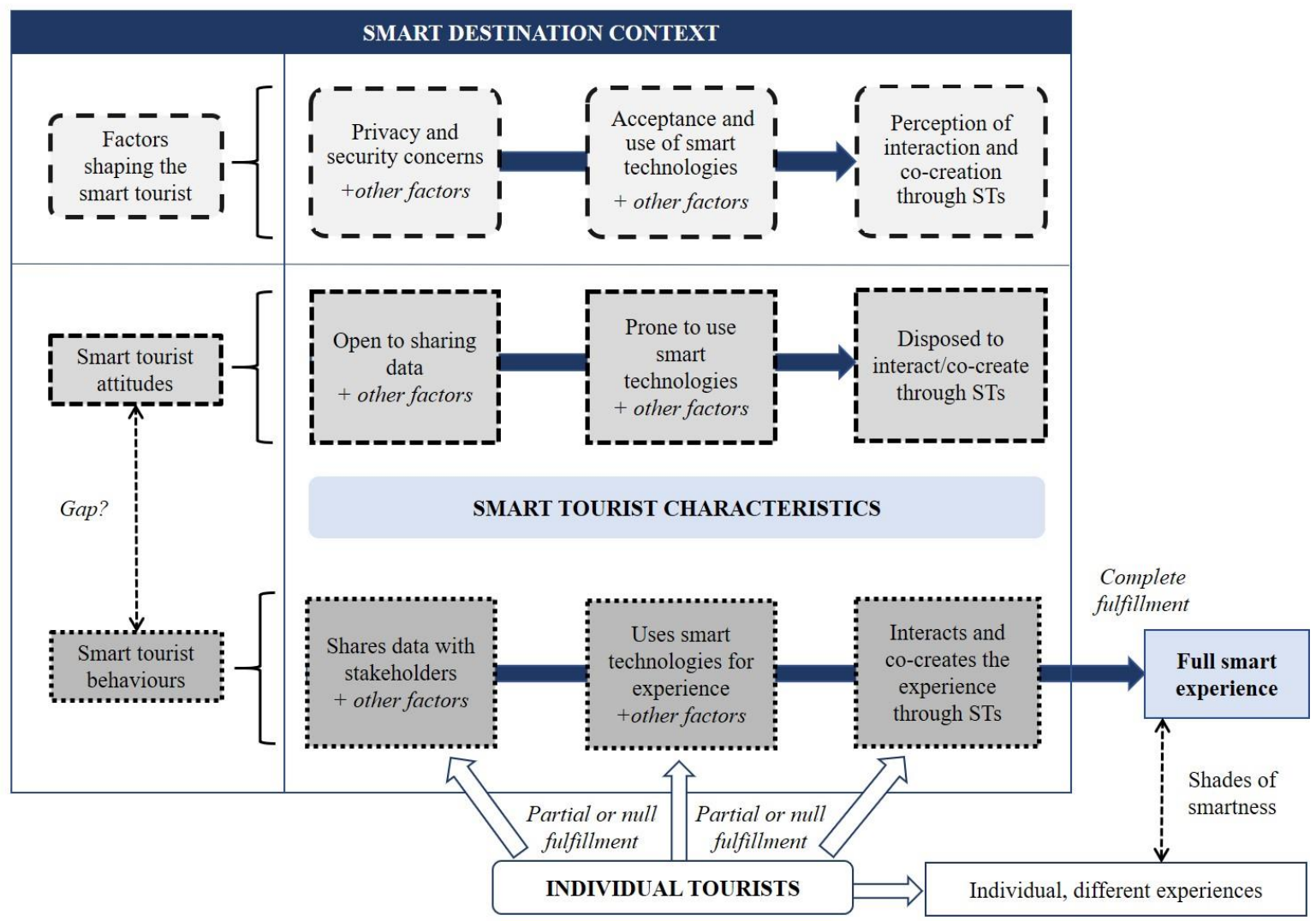


A more in-depth explanation of the characteristics of the smart tourist is performed as follows. To further strengthen this conceptualisation, in the following subheadings we provide evidence which illuminate the incipient shift of tourists' behaviour in these scopes and the progressive consolidation of a smart tourist in different degrees of fulfilment of the established characteristics. Additionally, a triangulation of sources is performed as this description is combined with: a) several real cases from different tourism subsectors which constitute best practices in the understanding of the smart tourist behaviour, $b$ ) data from businesses of the smart ecosystem (e.g. telecom and digital companies), and $c$ ) findings from recent contributions by academia. This is in line with the conceptual research standard practice of using existing, apparently diffuse, prior observations to support new connections and build original conceptual frameworks (Xin et al., 2013).

(1) Shares data with stakeholders

The smart tourist is an open tourist who shares their data (e.g. basic personal information, preferences, social media profiles information, location and movement, expenditures...) with other smart stakeholders as long as they feel confident with the potential use of that data. These tourists adopt the sharing of personal information as usual practice because they understand the benefits they will obtain are worthwhile and because they assume that their privacy and security will be protected. Smart tourists are therefore disposed to share their personal and preferences-related data to get tailored information and proposals while being conscious of the value of their data and the need to protect them.

An example of how smart tourists are starting to share their personal data with other stakeholders is the increasing use of recommendation and personalisation systems for trip planning, offered in many cases by official destination websites. One interesting case, for being a world recognised destination, is the city of San Francisco. By employing the Utrip recommender system, SF offers highly personalised itineraries to their visitors, adjusted to their interests and motivations, budget and preferred level of spontaneity. Tourists select on the destination website their personal preferences and in doing so exchange their trip related data (length of stay, budget, first visit or repeat visitation, personal appeals...) with the DMO, which will get a closer understanding of its visitors profiles through the mining of that data. Tourists are encouraged furthermore to share their tailored itinerary on their social media, involving other potential tourists. The success of the application among tourists has moved many other destinations (Seattle, Chicago, Nashville...) to implement the system while new partnerships and funds have also supported the initiatives (Nickelsburg, 2017). 
In consonance with this illustrative lesson, Neuhofer et al. (2015) found that tourists are usually open to sharing their personal information in exchange of better services provided through smart technologies. This is consistent with Herrero et al. (2017) results, which prove that tourists are normally predisposed to disclose information about their experiences when sharing them on social networks. According to a recent report by UNWTO (2017) seven out of ten tourists post photos about their trips on social media, thus sharing their more personal experiences with other users.

(2) Uses smart technologies for their experience

On their path towards the smart experience, smart tourists employ smart technologies and use them intensively for many dimensions of their experience. Smart tourists utilise STs to develop and enrich their experience, because they have the trust, will and ability and circumstances to do so. Smart tourists however will only use smart technologies they judge as useful, easily controllable and enriching. This way, too intrusive technologies or not providing a clear value may be discarded by smart tourists.

In this regard, museums have become field trials for the implementation of smart technologies that enhance the visitors' experience, and users have embraced them. The more innovative proposals make tourists the lead designers of their whole experience through the use of advanced technologies. A remarkable example is the great success among visitors of the ARTLENS Gallery at the Cleveland Museum of Art. In this part of the museum, smart technologies become the best allies of visitors and are used for many dimensions of the experience, which is based on discovering and learning about art, but also playing and engaging with other users. The gallery combines an advanced smartphone app featuring augmented reality and personalised interactive real-time maps with several touchscreens, motion and gesture-based games and a giant digital wall which interacts with the app and allows the users to get information about the artworks. Immersive technologies foster a direct physical interaction with the paintings and sculptures through games, and a welcome screen is employed to display the content created by visitors (pictures, digital drawings) while playing and learning. A 30\% increase in visitation since the opening of the gallery in 2013 (Alexander, Wienke \& Tiongson, 2017) proves the great success and the predisposition of visitors, among which tourists are a big share, to use smart technologies for their experiences. In line with this, recent research has proven that smart technologies can act as enablers of smart experiences (Huang et al., 2017), making the tourist an active part in the design of 
more tailored experiences. According to Oracle (2016), younger tourists are also starting to use smart technologies in the hospitality context in different dimensions of their experiences, and the smartphone seems to be the preferred tool to do so: a $20 \%$ of millennials have already checked-in to a hotel through a mobile device, a $12 \%$ have used it to order room service, and a 55\% state they want to be able to connect their smartphones to the room media to enjoy their personal entertainment. This concurs with previous research (e.g. D. Wang et al, 2012; 2016) that highlights the potential of smartphones to mediate and transform the experience in many levels, taking it to a superior stage.

(3) Interacts and co-creates the experience through smart technologies

Finally, smart tourists are active users of smart technologies, not only to enhance their own experience, but to perform a dynamic, real-time interaction and co-creation with other stakeholders in the SD service ecosystem. This way, they make use of STs for many dimensions of their experience jointly with other actors. This constitutes a critical step headed to the smart experience and expands the options for co-creation, involving different stakeholders. To develop this interaction and co-creation process, smart tourists need to trust stakeholder(s) in each situation, feeling they still have control over the experience by employing smart technologies according to their needs and preferences, but involving voluntarily other agents because they will get added value by doing so.

A representative case of how tourists have begun to use STs to co-create experiences with other stakeholders when the required conditions are met is provided by the recent implementation in Mallorca of the first 'twitter experience hotel'. In this hotel, guests become members of a twitter community that allows direct interaction among them, but also the sharing of experiences in the hotel and at the destination by using a common hashtag (\#SocialWave), often combined with the one for the destination (\#Mallorca). Tourists can furthermore utilise the twitter community to contact specialised hotel staff members ('Twitter concierges') through @ SolWaveHouse to ask for any service in real time, like ordering food or drinks. This way, tourists open up their social media profiles with the hotel and other travellers, and share their pictures and stories (thus sharing part of their personal information). By employing their mobile devices and social media and combining these STs to interact dynamically, tourists co-create at a superior level and get a unique smart experience. The hotel reviews on the internet and guests' comments show the support for this initiative and exemplify how some tourists are shifting their behaviour in the smart connected environment. 
Research has also shown support for the potential and benefit of STs to interact and co-create experiences involving other stakeholders, paying particular attention to social media as the preferred channel. As reflected by Munar \& Jacobsen (2014), tourists who share their experiences on social media do it in order to help other travellers in their decisions, create content for websites they like, strengthen social connections and obtain recognition. Apart of storing and sharing their experiences, tourists use social media to obtain information which in many cases is very current and generated by individual users (Xiang \& Gretzel, 2010). In the case of more tech-savvy tourists, these also wish to co-live and co-create their experiences with other people through these media, as Neuhofer (2016) proves. Besides, according to Buonincontri \& Micera (2016), some advanced DMOs are already leveraging these wishes and are capable of co-creating with tourists by using smart technologies, becoming an integral part of the smart experience development. As stated by Buhalis \& Foerste (2015), there is still a great potential to exploit the co-creation of experiences in destinations by dynamically involving all the stakeholders with the tourist through smart technologies.

Building on the above considerations, this paper proposes to define the smart tourist as:

The tourist who, by being open to sharing his or her data and making use of smart technologies, interacts dynamically with other stakeholders, co-creating in this way an enhanced and personalised smart experience. This tourist is open to innovations, social and pro-active and finds his or her natural environment in the smart tourism ecosystem and the smart destination.

This definition does not intend to mean that the smart tourist is a homogeneous type of tourist. Instead, it is argued here that there are different 'grades of smartness' in every tourist depending on their level of fulfilment of the depicted attributes. It is obvious that many tourists will not fulfil them, or just some of them, and still interact somehow with the proclaimed SD. These enriching nuances (in Fig. 2: shades of smartness) introduce a full range of possibilities for more or less smart behaviours and experiences in the SD and force destinations to adapt their strategies to this heterogeneous reality. This way, it is particularly relevant to take into account these existing shades of smartness among tourists. In reality, some tourists might want to share some of their data but not others, to use some technologies but not others, and also to co-create in some situations and with some stakeholders but not with others. There might exist, as noted in figure 2, a gap between smart tourists' attitudes and behaviours, a gap which is widely discussed in behavioural studies (Venkatesh et al., 2003). This way, some tourists can show a predisposition to share their data, use smart 
technologies and interact with other stakeholders, but lack the ability, resources or good circumstances to do so. Apart from the already mentioned privacy and security concerns, some other constraints or factors can jeopardise the crystallisation of the expected behaviours (e.g. lack of technological skills, budget limitations, legal restrictions, etc). Thus, although it seems that many technologies have become commonplace and tourists have widely adopted them, the truth is some tourists do not have access yet to these tools, or do not want to make use of them. This diversity is here acknowledged as valuable, and also challenging.

The complexity behind privacy concerns, smart technologies use or willingness to use these to co-create with other stakeholders, necessarily implies admitting this diverse nature of tourists and contexts. This increasingly recognised intricacy of tourists' decision-making process challenges traditional planned behaviour models, as situational factors, emotions, interpersonal relationships and the particular context of travellers seem also to play an important role in tourists' decisions and behaviour (Cohen et al., 2014). Moreover, the behaviours of these smart tourists answer to more profound motivations and values, socioeconomic/psychographic traits, life cycle stage and other variables which need to be addressed in detail.

At this point, this paper goes beyond the developed conceptualisation of the smart tourist and contextualises its role in the broader context of the smart destination to offer a further theoretical contribution to current literature.

\section{Smart tourist's role within SDs}

The conceptual model displayed in Figure 3 represents the overall position of the smart tourist in relation to the rest of the elements and players in the wider SD and global smart service ecosystem. Based on the provided review of the current smart context and definition of smart tourists, their role is here introduced, including the data flows and existing relationships within the SD. 
Figure 3, Smart tourist's role within the smart destination scenario

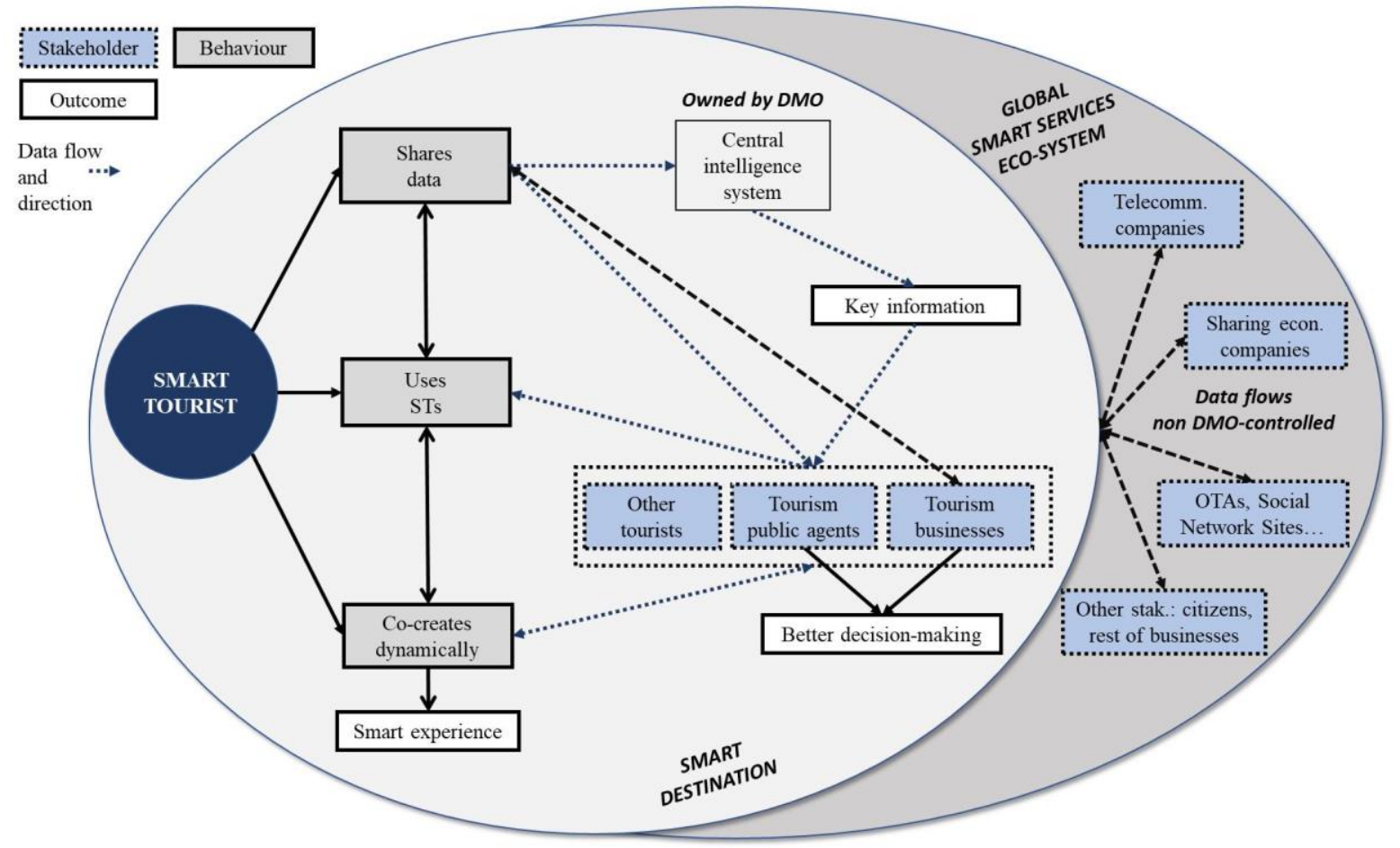

This model captures how smart tourists, through the actions that constitute their behaviour, start the 'engine' of the smart destination 'machinery'. Ideally, data sharing and the use of smart technologies generate the data that fuels the central intelligence system, which, after filtering, provides key information to stakeholders. DMOs and businesses are able to make better decisions thanks to this information, which improves their capacity to design better services and experiences with tourists. All the stakeholders together employ STs to dynamically co-create the experience with the smart tourist, and continue generating data that guarantee a proper functioning of the system. The co-created smart experience is reached when the pieces of the machinery function properly. However, several uncertainties put this idealised model at risk. The interaction of the smart tourist with the broader smart tourism ecosystem is complex and many uncontrolled flows of data jeopardise the vision of the DMO controlling the whole process. 'Outside' players generate huge amounts of data on tourists that remain out of the DMOs' control. This way, technology companies owning parts of the big data can be somewhat non-collaborative with a tendency to compete rather than to cooperate. Plus, destinations may lack the capacity or will to merge the different data sources and utilise them harmonically. It can also happen that tourists' use of technology cannot be handled by destinations that are not ready to respond properly. There has to be a twofold compromise to adapt, but destinations need to keep in mind that they are the ones that have to 
fulfil tourists' needs and preferences to increase their satisfaction through enhanced experiences.

Besides, it needs to be emphasised that even though technology is provided by third parties and within this ecosystem players with blurred roles emerging and evolving rapidly (Gretzel, Werthner, et al., 2015), smart tourists have to be in control. This means that they will only share their data if they feel secure about it and get value in exchange, will use technology if they feel it is useful and enriching for them and will co-create only if they wish to do so. They have control as long as they are free to make these choices voluntarily. In any case, the role of smart tourists remains crucial.

For the moment, the smart tourist is still 'under construction', with many realities co-existing and making the smart destination an intricate context in which scalable strategies will have to be adopted to cope with them. The expectations shown in the above-depicted smart tourist role model may still have to wait until they are met by a majority of tourists, but at the same time it seems that these emerging smart tourists' behaviours have become a driving force for the development of SDs. Their preferences might not be totally satisfied in 'traditional' destinations or by firms. For this reason, these should adopt the smartness paradigm for not losing competitiveness among other destinations and the global tourism ecosystem in which big players are in the forefront of the adaptation to the smart tourist.

In conclusion, this conceptual development of smart tourists and the characterisation of their role within SDs bring to surface many theoretical and managerial implications and represent relevant perspectives to bridge the gap between theory and practice.

\section{Conclusions and Implications}

Smartness has recently emerged as a framework for the understanding of tourism in a context in which ICTs have already reshaped the entire industry and transformed experiences and behaviours of tourists. Yet, research on smart tourism to date has partially ignored tourists' role from a holistic perspective, usually focusing on the adoption and use of particular technologies. However, a global interpretative framework in this regard for the smart context was missing. To tackle this shortcoming, this paper has contributed first, by proposing a deeper conceptualisation that characterises smart tourists through a description of their attitudes and behaviours, and second, by defining their role in the smart destination scenario. The paper concludes that the role of the tourist must be central in smart tourism and calls for 
a better strategic decision making. The findings offer several critical implications for research, DMOs and businesses operating in the smart services setting, and highlight possible research lines for a topic that is still in its infancy.

\section{Theoretical contribution}

This paper has contributed to current smart tourism literature in many ways. First, drawing on literature-based identified factors, the critical shift from the digital to the smart tourist has been conceptualised and framed in relevant theories which shed light on this transformation. The privacy concern, deemed as critical for smartness by previous contributions in the field (e.g. Buhalis \& Amaranggana, 2014, 2015; González-Reverté et al., 2018; Huang et al., 2017; Xiang \& Fesenmaier, 2017) has been explored, and its impact over the rest of the functioning of the system has been emphasised. Privacy plays a particularly relevant role in smart destinations across many issues, such as the use of location-based services (Anuar \& Gretzel, 2011), which combined with smartphones are core technologies for the new functioning of destinations. Moreover, the crucial intermediation and great potential of smart technologies in tourist experiences (D. Wang et al., 2012; 2016), has been contrasted with the necessary acceptance and use of these by tourists, bridging the theories on technology acceptance and the omnipresence of STs in current tourist experience literature. Finally, dynamic co-creation with all stakeholders thanks to the use of smart technologies has been argued to be the final step towards the smart experience, taking the experience co-creation to a higher level in the SD (Buonincontri \& Micera, 2016; Neuhofer et al., 2015). This way, linking the smart destination concept to current critical factors affecting tourists in a cuttingedge technological context has served to introduce the smart tourist conceptualisation (Fig. 2). This conceptualisation has captured how tourists are adapting to this new smart service ecosystem while at the same time they wish to retain the power to decide how to use technologies to co-create value with the rest of stakeholders at the destination.

By carrying out this theoretical exercise, this paper has tackled the lack of a deep examination of the relationship between tourists and technology within the context of smart tourism, responding to the need detected by several scholars (Buonincontri \& Micera, 2016; Gretzel, Reino, et al., 2015; Gretzel, Sigala, et al., 2015; Gretzel, Werthner, et al., 2015; Xiang \& Fesenmaier, 2017), and creating new perspectives for future empirical research. The conceptualised type of tourist is furthermore supported with examples of real cases of best practices in several tourism industries in their effort to adapt to this smart traveller/consumer, but also with data provided by technology companies operating in the smart service 
ecosystem. All of these are framed within recent academic empirical evidence. Moreover, the profiling of the smart tourist has been related to the role it plays in the wider SD, presented in a second model (Fig.3). This model also contributes to research in that it defines the different processes, flows of data and relationships that exist within a smart destination. But most of all, it positions the tourists in the current smart service ecosystem and establishes the implications that their actions have over the rest of the 'chain' that leads to the anticipated smart experience.

\section{Managerial implications}

This paper's contribution suggests some managerial implications for both DMOs and businesses in the smart tourism scenario. First, the proposed theoretical perspectives for smart tourists and destinations call for the creation and maintenance of a technological infrastructure by DMOs. In line with this, part of the smart technologies infrastructure (sensors, beacons, official apps, etc.) relies directly on public investment for their functioning, which requires destinations to make constant efforts to develop and keep them updated. However, the constant evolution of ICTs requires these organisations to consider opportunities and risks of implementing each specific technological solution. It remains unknown which exact direction technology will take and which concrete applications will finally succeed, so strategic planning is needed more than ever. The acceptance and use of STs are crucial in the smart destination scenario. Therefore, taking into account current acceptance and use levels of each specific ST before investing is crucial. Additionally, once implemented, it is critical to assess the real impact of technologies on demand satisfaction, rendering feedback from tourists a valuable information source to examine the results of smart projects and initiatives. Moreover, the position and perceived image of each destination regarding its 'smartness level' could also affect tourists and destinations strategies. Therefore, it would be interesting for destinations to self-assess in this regard. It is also needed to better understand how different types of destinations (rural vs urban, cultural vs beach resorts, etc.) may generate different levels of expectation, attitudes and behaviours from tourists regarding the depicted dimensions of technology use. Furthermore, the lack of connectivity might still be an issue in some geographic areas, such as rural destinations, and constitutes a notable barrier for smart destinations construction. As acknowledged by Magasic \& Gretzel (2017), tourists can encounter different levels of connectivity depending on their destination or trip type, ranging from high connectivity (residential connectivity) to limited connectivity (transit connectivity), or even total or large disconnection from the 
internet (remote mode). Either situation has consequences over tourists and their experiences. Being connected for instance has positive effects (e.g. social connectedness, high engagement, information availability, efficiency in actions), but also negative (e.g. inability to relax, unsociability, information overload, self-pressure to use ICTs, etc.) (Neuhofer, 2016; Tanti \& Buhalis, 2016). Therefore, SDs will have to design scalable strategies for different possible situations regarding connectivity levels and their consequences for visitors' and their behaviours.

Second, in afore-described intricate smart destination scenario, the DMO has to act as a coordinator and facilitator of flows and relations. DMOs ought to foster strong collaboration, and the central intelligence system of a SD is a powerful tool to advance in this direction. Public or mixed agents should be the ones owning technological platforms and infrastructure, gathering different data sources to transform them into key information to distribute it to different stakeholders. This would ensure responsibility as well as efficiency (Gretzel, Reino, et al., 2015). Furthermore, destinations and governments have to promote the interoperability of systems to ensure that tourists can navigate easily, to reinforce the coordination and flow of data and to support a seamless communication of tourists within the destination and also with their country of origin, for instance by revoking all types of roaming. In line with this, tourists in different countries use different software, search engines or social media platforms, so destinations may need to be present in the most popular channels of their potential markets, ensuring an appropriate communication strategy through the right channels for the different tourist segments.

Third, privacy and security concerns should be high on the list of priorities of managers due to their relevance for a full development of smart experiences. Solutions in this matter have to be established in SD projects by DMOs and enterprises. A more direct, transparent communication between businesses, DMOs and consumers could be highly beneficial and reinforce mutual trust that facilitates tourists to share their data. A simpler, straightforward 'contract' that assures tourists' interests and informs them clearly of the use of their data (rather than typical 'terms and conditions'), could positively influence their predisposition to share personal data (Buhalis \& Amaranggana, 2015; Lee \& Cranage, 2011). Nevetheless, some other aspects could influence this privacy concern, such as the benefits associated with the use of certain apps, the type of destination and trip, familiarity with services providers or the individual user's characteristics (Anuar \& Gretzel, 2011). 
In conclusion, the acknowledgement of smart tourists and their role in the SD brings to surface significant implications for SDs, namely a) strategic planning and a strong public involvement in the technological development and smart technology implementation is required for a long-term success, $b$ ) in SDs, DMOs ought to act as coordinators, should provide the technological infrastructure and ensure a good data management as much as possible, c) SDs need to reinforce the trust between tourists, companies and public agents regarding data treatment, while taking real actions to ensure no misuse of tourists' data is done.

\section{Limitations and future research}

This paper has presented a conceptual model which constitutes just a first step in extending our knowledge on the smart tourist, so several limitations have to be acknowledged to foster further research.

First, the smart destination can be conceptualised from many different perspectives which, especially in institutional plans, emphasise the possibilities new ICTs offer in aspects such as sustainability, accessibility or innovation (López de Ávila \& García, 2013). These scopes might offer interesting insights for a better understanding of the wider context of the smart tourist. Moreover, in line with this broader perspective, a detailed study of the interactions of the tourist with each of the actors in the smart tourism service ecosystem is highly needed. Second, while this paper has profiled an emerging type of tourist, can this smart tourist be considered a market segment itself? According to Dolnicar \& Matus (2008), elaborating on Kotler's and other prior contributions on the segmentation field, several requirements need to be met to consider new market segments, such as: measurability, accessibility, substantiality, differentiability, actionability, stability and responsiveness. Based on these or similar requisites, empirical studies will have to investigate if there is a clear smart tourist segment or if we can even develop a typology of smart tourists. In relation with this, although used in this paper in a narrow sense, the 'role' concept can offer some interesting insights. The different degrees of compliance with the established smart tourist characteristics could be employed to create a typology of tourists according to their level of adoption of the smart tourist role, as has been previously done by authors who have used the Goffmanian framework to develop typologies of roles (e.g. Wickens, 2002). Defining a strategy to address the relationship between DMOs and companies and each of the detected types of smart tourists would bring to light more valuable managerial insights. 
Additionally, the proposed smart tourist conceptualisation needs to be supported by a broader empirical research to strengthen its validity to further comprehend tourists in the smart paradigm, and to address the still pending knowledge gaps around the tourist in this scenario. It is hoped that the present research illuminates the process and provides coherent foundations to explore this scope. Finally, research on smart tourism needs to develop a more critical approach to the topic. In line with this, an enriching comparison is that of the "smart citizen' in relation to the smart city paradigm (Hemment \& Townsend, 2013) and the inspiration it can serve for the new coupling smart tourist-smart destination. Elaborating on this analogy, smart tourists would not only be the ones that better adapt to the conditions as they are, but also the ones that take a leading role and decide how they want smart destinations to be. Under this perspective, tourists would take a pro-active role in the design and implementation of technological solutions which are fitted to their actual needs and preferences. This would probably address some of the referred critical issues such as privacy and security concerns and use of certain technologies. Decision-making process would be this way reverted in favour of tourists. Nevertheless, while this bottom-up approach is much needed, engaging tourists in deciding how they want their destination to use the technology to engage with them seems pretty complicated for now. Instead, SDs could focus for the moment on assuring that the technological implementations are consumer-centric and benefit tourists' interests above all. SDs need to assure each tourist has the power to decide whether they want a connected smart experience or not. ICTs should not become an imposition but rather an opportunity for those who want to embrace them. Besides, the more or less technocentric perspective taken by public projects and the ethical values implicit in these are paramount. Exploring these matters is a task that has to be undertaken.

\section{Acknowledgments}

"Research carried out within the project 'Analysis of planning processes applied to smart cities and smart tourism destinations. Balance and methodological proposal for tourist spaces: Smart Tourism Planning' (CSO2017-82592-R) under the Spanish National R\&D\&I Plan and Grant no. BES-2015-073909, funded by the Ministry of Economy, Industry and Competitiveness"

\section{References}

Ajzen, I., \& Fishbein, M. (1977). Attitude-Behavior Relations: A Theoretical Analysis and Review of Empirical Research. Psychological Bulletin, 84(5), 888-918. http://doi.org/10.1037/0033-2909.84.5.888

Alexander, J., Wienke, L., \& Tiongson, P. (2017). Removing The Barriers Of Gallery One: A 
New Approach To Integrating Art, Interpretation, And Technology. Museums and the Web 2017 Conference. Cleveland (United States), April 17-22. Retrieved from: https://mw17.mwconf.org/paper/removing-the-barriers-of-gallery-one-a-new-approachto-integrating-art-interpretation-and-technology/

Anuar, F. I., \& Gretzel, U. (2011). Privacy Concerns in the Context of Location-Based Services for Tourism. e-Review of Tourism Research, 1. Research notes ENTER 2011. Retrieved from http://ertr.tamu.edu/files/2013/02/13.pdf

Baggio, R., \& Cooper, C. (2010). Knowledge transfer in a tourism destination: the effects of a network structure. The Service Industries Journal, 30(10), 1757-1771. https://doi.org/10.1080/02642060903580649

Benckendorff, P. J., Sheldon, P. J., \& Fesenmaier, D. R. (2014). Tourism Information Technology (2nd Ed.). Wallingford: CABI.

Binkhorst, E., \& Dekker, T. Den. (2009). Agenda for co-creation tourism experience research. Journal of Hospitality Marketing \& Management, 18(2-3), 311-327. http://doi.org/10.1080/19368620802594193

Boes, K., Buhalis, D., \& Inversini, A. (2015). Conceptualising Smart Tourism Destination Dimensions. In I. Tussyadiah \& A. Inversini (Eds.), Information and Communication Technologies in Tourism 2015 (pp. 391-403). Cham: Springer. http://doi.org/10.1016/S0160-7383(01)00012-3

Boes, K., Buhalis, D., \& Inversini, A. (2016). Smart tourism destinations: ecosystems for tourism destination competitiveness. International Journal of Tourism Cities, 2(2). http://doi.org/10.1108/IJTC-12-2015-0032

Bonsón Ponte, E., Carvajal-Trujillo, E., \& Escobar-Rodríguez, T. (2015). Influence of trust and perceived value on the intention to purchase travel online: Integrating the effects of assurance on trust antecedents. Tourism Management, 47, 286-302. http://doi.org/10.1016/j.tourman.2014.10.009

Bornhorst, T., Ritchie, J. R. B., \& Sheehan, L. (2010). Determinants of tourism success for DMOs \& destinations: An empirical examination of stakeholders' perspectives. Tourism Management, 31(5), 572-589. http://doi.org/10.1016/j.tourman.2009.06.008

Brown, M. R., Muchira, R., \& Gottlieb, U. (2007). Privacy Concerns and the Purchasing of Travel Services Online. Information Technology \& Tourism, 9(1), 15-25. http://doi.org/10.3727/109830507779637620

Buhalis, D. (2001). The tourism phenomenon. The new tourist and consumer. In S. Wahab \& C. Cooper (Eds.), Tourism in the Age of Globalisation (pp. 69-96). London: Routledge.

Buhalis, D. (2003). eTourism: Information technology for strategic tourism management. Harlow: Pearson Education.

Buhalis, D., \& Amaranggana, A. (2014). Smart tourism destinations. In Z. Xiang \& I. Tussyadiah (Eds.), Information and Communication Technologies in Tourism 2014 (pp. 553-564). Cham: Springer. http://doi.org/10.1007/978-3-319-03973-2

Buhalis, D., \& Amaranggana, A. (2015). Smart Tourism Destinations Enhancing Tourism Experience Through Personalisation of Services. In I. Tussyadiah \& A. Inversini (Eds.), Information and Communication Technologies in Tourism 2015 (pp. 377-389). Cham: Springer. http://doi.org/10.1007/978-3-319-14343-9_28

Buhalis, D., \& Foerste, M. (2015). SoCoMo marketing for travel and tourism: Empowering co-creation of value. Journal of Destination Marketing \& Management, 4(3), 1-11. http://doi.org/10.1016/j.jdmm.2015.04.001

Buhalis, D., \& Law, R. (2008). Progress in information technology and tourism management: 20 years on and 10 years after the Internet-The state of eTourism research. Tourism Management, 29(4), 609-623. http://doi.org/10.1016/j.tourman.2008.01.005

Buonincontri, P., \& Micera, R. (2016). The experience co-creation in smart tourism 
destinations: a multiple case analysis of European destinations. Information Technology \& Tourism, 16(3), 285-315. http://doi.org/10.1007/s40558-016-0060-5

Choe, Y., \& Fesenmaier, D. R. (2017). The Quantified Traveler: Implications for Smart Tourism Development. In Z. Xiang \& D. R. Fesenmaier (Eds.), Analytics in Smart Tourism Design (pp. 65-77). Switzerland: Springer.

Cohen, E. (1972). Toward a sociology of international tourism. Social Research, 39(1), 164 182

Cohen, E. (1974). Who Is a Tourist?: A Conceptual Clarification. The Sociological Review, 22(4), 527-555. http://doi.org/10.1111/j.1467-954X.1974.tb00507.x

Cohen, E. (1979). A phenomenology of tourist experiences. Sociology, 13(2), 179-201.

Cohen, S. A., Prayag, G., \& Moital, M. (2014). Consumer behaviour in tourism: Concepts, influences and opportunities. Current Issues in Tourism, 17(10), 1872-1909. http://doi.org/10.1080/13683500.2013.850064

d'Angella, F., \& Go, F. M. (2009). Tale of two cities' collaborative tourism marketing: Towards a theory of destination stakeholder assessment. Tourism Management, 30(3), 429-440. http://doi.org/10.1016/j.tourman.2008.07.012

Davis, F. D. (1989). Perceived Usefulness, Perceived Ease of Use, and User Acceptance of Information Technology. MIS Quarterly, 13(3), 319-340. http://doi.org/DOI: $10.2307 / 249008$

Davis, F. D., Bagozzi, R. P., \& Warshaw, P. R. (1989). User acceptance of computer technology: a comparison of two theoretical models. Management Science, 35(8), 9821003.

Del Chiappa, G., \& Baggio, R. (2015). Knowledge transfer in smart tourism destinations: Analyzing the effects of a network structure. Journal of Destination Marketing \& Management, 30(10), 1757-1771. http://doi.org/10.1016/j.jdmm.2015.02.001

Dolnicar, S., \& Matus, K. (2008). Are green tourists a managerially useful target segment? Journal of Hospitality and Leisure Marketing, 17(3-4), 314-334. http://doi.org/10.1080/10507050801984826

González-Reverté, F., Díaz-Luque, P., Gomis-López, J. M., \& Morales-Pérez, S. (2018). Tourists' Risk Perception and the Use of Mobile Devices in Beach Tourism Destinations. Sustainability, 10(2), 1-21. http://doi.org/10.3390/su10020413

Gretzel, U. (2011). Intelligent systems in tourism. A Social Science Perspective. Annals of Tourism Research, 38(3), 757-779. http://doi.org/10.1016/j.annals.2011.04.014

Gretzel, U., Fesenmaier, D. R., \& O'Leary, J. T. (2006). The transformation of consumer behaviour. In D. Buhalis \& C. Costa (Eds.), Tourism business frontiers: Consumers, products and industry (pp. 9-18). Oxford: El Sevier Butterworth-Heinemann.

Gretzel, U., \& Jamal, T. (2009). Conceptualizing the creative tourist class: technology, mobility, and tourism experiences. Tourism Analysis, 14(4), 471-481. http://doi.org/10.3727/108354209X12596287114219

Gretzel, U., Reino, S., Kopera, S., \& Koo, C. (2015). Smart Tourism Challenges. Journal of Tourism, 16(1), 41-47. http://doi.org/10.1108/JTF-12-2014-0023

Gretzel, U., Sigala, M., Xiang, Z., \& Koo, C. (2015). Smart tourism: foundations and developments. Electronic Markets, 25(3), 179-188. http://doi.org/10.1007/s12525-0150196-8

Gretzel, U., Werthner, H., Koo, C., \& Lamsfus, C. (2015). Conceptual foundations for understanding smart tourism ecosystems. Computers in Human Behavior, 50, 558-563. http://doi.org/10.1016/j.chb.2015.03.043

Gretzel, U., Zhong, L., \& Koo, C. (2016). Application of smart tourism to cities. International Journal of Tourism Cities, 1(3), 216-233. http://doi.org/http://dx.doi.org/10.1108/IJTC-08-2014-0014 
Hemment, D., \& Townsend, A. (2013). Smart citizens. Manchester: FutureEverything Publications.

Herrero, Á., San Martín, H., \& Garcia-De los Salmones, M. del M. (2017). Explaining the adoption of social networks sites for sharing user-generated content: A revision of the UTAUT2. Computers in Human Behavior, 71, 209-217. http://doi.org/10.1016/j.chb.2017.02.007

Huang, C. D., Goo, J., Nam, K., \& Yoo, C. W. (2017). Smart Tourism Technologies in Travel Planning: The Role of Exploration and Exploitation. Information \& Management, (In press). http://doi.org/10.1016/j.im.2016.11.010

Ivars-Baidal, J. A., Celdrán-Bernabeu, M. A., Mazón, J.-N., \& Perles-Ivars, Á. F. (2017). Smart destinations and the evolution of ICTs: a new scenario for destination management? Current Issues in Tourism, (In press), http://doi.org/10.1080/13683500.2017.1388771

Jovicic, D. Z. (2017). From the traditional understanding of tourism destination to the smart tourism destination. Current Issues in Tourism, (In press), http://doi.org/10.1080/13683500.2017.1313203

Kim, D. J., Ferrin, D. L., \& Rao, H. R. (2008). A trust-based consumer decision-making model in electronic commerce: The role of trust, perceived risk, and their antecedents. Decision Support Systems, 44(2), 544-564. http://doi.org/10.1016/j.dss.2007.07.001

Koo, C., Park, J., \& Lee, J.-N. (2017). Smart tourism: Traveler, business, and organizational perspectives. Information \& Management, 54, 683-686. http://doi.org/10.1016/j.im.2017.04.005

Koo, C., Shin, S., Kim, K., Kim, C., \& Chung, N. (2013). Smart Tourism of the Korea: a Case Study. In Proceedings of Pacific Asia Conference on Information Systems 2013 (PACIS 2013), June 18-22, Jeju, Korea (n.p.).

Koo, C., Yoo, K.-H., Lee, J.-N., \& Zanker, M. (2016). Special section on generative smart tourism systems and management: Man-machine interaction. International Journal of Information Management, 36(6), 1301-1305. http://doi.org/10.1016/j.ijinfomgt.2016.05.015

Lamsfus, C., Martín, D., Alzua-Sorzabal, A., \& Torres-Manzanera, E. (2015). Smart tourism destinations: An extended conception of smart cities focusing on human mobility. In I. Tussyadiah \& A. Inversini (Eds.), Information and Communication Technologies in Tourism 2015 (pp. 363-375). Cham: Springer.

Lee, C. H., \& Cranage, D. A. (2011). Personalisation-privacy paradox: The effects of personalisation and privacy assurance on customer responses to travel Web sites. Tourism Management, 32(5), 987-994. http://doi.org/10.1016/j.tourman.2010.08.011

Li, Y., Hu, C., Huang, C., \& Duan, L. (2016). The concept of smart tourism in the context of tourism information services. Tourism Management, 58, 293-300. http://doi.org/10.1016/j.tourman.2016.03.014

Liberato, P., Alen, E., \& Liberato, D. (2018). Smart tourism destination triggers consumer experience: the case of Porto. European Journal of Management and Business Economics, 27(1), 6-25. http://doi.org/10.1108/EJMBE-11-2017-0051

López de Ávila, A., \& García, S. (2013). Destinos Turísticos Inteligentes. Economía Industrial, (395), 61-69. $\quad$ Retrieved from http://www.minetad.gob.es/Publicaciones/Publicacionesperiodicas/EconomiaIndustrial/ RevistaEconomiaIndustrial/395/LOPEZ DE AVILA y GARCIA.pdf

Luque-Martínez, T., Alberto Castañeda-García, J., Frías-Jamilena, D. M., Muñoz-Leiva, F., \& Rodríguez-Molina, M. A. (2007). Determinants of the use of the internet as a tourist information source. The Service Industries Journal, 27(7), 881-891.

MacCannell, D. (1976). The Tourist: A new theory of the leisure class. New York: Schocken 
books.

Magasic, M. \& Gretzel, U. (2017). Three Modes of Internet Connectivity during Travel: Remote, Transit and Residential. e-Review of Tourism Research, 8, Research notes ENTER 2017. Retrieved from: https://agrilifecdn.tamu.edu/ertr/files/2016/12/RN1601.pdf

McCabe, S. (2005). "Who is a tourist?": A critical review. Tourist Studies, 5(1), 85-106. http://doi.org/10.1177/1468797605062716

Micera, R., Presenza, A., Splendiani, S., \& Del Chiappa, G. (2013). SMART Destinations: new strategies to manage tourism industry. In 8th International Forum on Knowledge Asset Dynamics: Smart growth: Organizations, cities and communities (IFKAD) (pp. 1405-1422). Zagreb: Emerald. http://doi.org/http://dx.doi.org/10.1108/MBE.26717daa.001

Munar, A. M., \& Jacobsen, J. K. S. (2014). Motivations for sharing tourism experiences through social media. Tourism Management, 43, 46-54. http://doi.org/10.1016/j.tourman.2014.01.012

Neuhofer, B. (2016). Value co-creation and co-destruction in connected tourist experiences. In A. Inversini \& R. Schegg (Eds.), Information and communication technologies in tourism 2016 (pp. 779-792). Cham: Springer.

Neuhofer, B., Buhalis, D., \& Ladkin, A. (2012). Conceptualising technology enhanced destination experiences. Journal of Destination Marketing and Management, 1(1-2), 36-46. http://doi.org/10.1016/j.jdmm.2012.08.001

Neuhofer, B., Buhalis, D., \& Ladkin, A. (2015). Smart technologies for personalized experiences: a case study in the hospitality domain. Electronic Markets, 25, 243-254. http://doi.org/10.1007/s12525-015-0182-1

Nickelsburg, M. (2017) Utrip raises $\$ 4 \mathrm{M}$ to build out artificial intelligence-based travel planning platform. Geek Wire. Retrieved from https://www.geekwire.com/2017/utripraises-4m-build-artificial-intelligence-based-travel-planning-platform/

Oracle. (2016). Millennials and Hospitality: The Redefinition of Service. Retrieved from https://go.oracle.com/LP=26913?elqCampaignId=40171

Park, J. H., Lee, C., Yoo, C., \& Nam, Y. (2016). An analysis of the utilization of Facebook by local Korean governments for tourism development and the network of smart tourism ecosystem. International Journal of Information Management, 36(6), 1320-1327. http://doi.org/10.1016/j.ijinfomgt.2016.05.027

Pearce, D. G. (2014). Toward an Integrative Conceptual Framework of Destinations. Journal of Travel Research, 53(2), 141-153. http://doi.org/10.1177/0047287513491334

Pearce, P. L. (2011). Tourist behaviour and the contemporary world. Bristol: Channel view publications.

Prahalad, C. K., \& Ramaswamy, V. (2004a). Co-creating unique value with customers. Strategy \& Leadership, 32(3), 4-9.

Prahalad, C. K., \& Ramaswamy, V. (2004b). Co-creation experiences: The next practice in value creation. Journal of Interactive Marketing, 18(3), 5-14.

Ryan, C., Minghui, S., Xiaoyu, Z., Fangxuan, L., Ping, L., Jun, G., ... Lin, H. (2016). Illustrations of Chinese tourism research. Tourism Management, 58, 229-234. http://doi.org/10.1016/j.tourman.2016.03.006

Saarinen, J. (2004). "Destinations in change." Tourist Studies, 4(2), 161-179. http://doi.org/10.1177/1468797604054381

Saraniemi, S., \& Kylänen, M. (2011). Problematizing the Concept of Tourism Destination: An Analysis of Different Theoretical Approaches. Journal of Travel Research, 50(2), 133-143. http://doi.org/10.1177/0047287510362775

Saravanan, S., \& Ramakrishnan, B. S. (2016). Preserving privacy in the context of location 
based services through location hider in mobile-tourism. Information Technology \& Tourism, 16(2), 229-248. http://doi.org/10.1007/s40558-016-0056-1

Sautter, E. T., \& Leisen, B. (1999). Managing stakeholders a Tourism Planning Model. Annals of Tourism Research, 26(2), 312-328. http://doi.org/10.1016/S01607383(98)00097-8

SEGITTUR. (2015). Informe destinos turísticos inteligentes: construyendo el futuro. Retrieved from http://www.segittur.es/opencms/export/sites/segitur/.content/galerias/descargas/proyecto s/Libro-Blanco-Destinos-Tursticos-Inteligentes-construyendo-el-futuro.pdf

Smith, H. J., Milberg, S. J., \& Burke, S. J. (1996). Information Privacy: Measuring Individuals' Concerns About Organizational Practices. MIS Quarterly, 167-196.

Tanti, A. \& Buhalis, D. (2016). Connectivity and the consequences of being (dis)connected. In A. Inversini, R. Schegg (eds.), Information and Communication Technologies in Tourism 2016, (pp. 31-44). Cham: Springer. http://doi.org/10.1007/978-3-319-2823123

Turner, L., \& Ash, J. (1975). The Golden Hordes: International Tourism and the Pleasure Periphery. London: Constable Ltd.

Tussyadiah, I. P., \& Fesenmaier, D. R. (2009). Mediating Tourist Experiences. Access to Places via Shared Videos. Annals of Tourism Research, 36(1), 24-40. http://doi.org/10.1016/j.annals.2008.10.001

UNWTO. (2017). Annual Report on Asia Tourism Trends. Retrieved from http://www2.unwto.org/es/node/49267

Uriely, N. (2005). The tourist experience. Conceptual developments. Annals of Tourism Research, 32(1), 199-216. http://doi.org/10.1016/j.annals.2004.07.008

Urry, J., \& Larsen, J. (2011). The Tourist Gaze 3.0. London: Sage Publications Limited.

Venkatesh, V., Morris, M. G., Davis, G. B., \& Davis, F. D. (2003). User acceptance of information technology: Toward a unified view. MIS Quarterly, 27(3), 425-478.

Venkatesh, V., Thong, J. Y. L., \& Xu, X. (2012). Consumer acceptance and use of information technology: extending the unified theory of acceptance and use of technology. MIS Quarterly, 36(1), 157-178.

Wang, D., Li, X. R., \& Li, Y. (2013). China's "smart tourism destination" initiative: A taste of the service-dominant logic. Journal of Destination Marketing \& Management, 2(2), 59-61. http://doi.org/10.1016/j.jdmm.2013.05.004

Wang, D., Park, S., \& Fesenmaier, D. R. (2012). The Role of Smartphones in Mediating the Touristic Experience. Journal of Travel Research, 51(4), 371-387. http://doi.org/10.1177/0047287511426341

Wang, D., Xiang, Z., \& Fesenmaier, D. R. (2016). Smartphone Use in Everyday Life and Travel. Journal of Travel Research, 55(1), 52-63. http://doi.org/10.1177/0047287514535847

Wang, X., Li, X. R., Zhen, F., \& Zhang, J. (2016). How smart is your tourist attraction?: Measuring tourist preferences of smart tourism attractions via a FCEM-AHP and IPA approach. Tourism Management, 309-320. http://doi.org/10.1016/j.tourman.2015.12.003

Wickens, E. (2002). The sacred and the profane: A tourist typology. Annals of Tourism Research, 29(3), 834-851.

Xiang, Z., \& Fesenmaier, D. R. (2017). Big Data Analytics, Tourism Design and Smart Tourism. In Z. Xiang \& D. R. Fesenmaier (Eds.), Analytics in Smart Tourism Design (pp. 299-307). Switzerland: Springer.

Xiang, Z., \& Gretzel, U. (2010). Role of social media in online travel information search. Tourism Management, 31(2), 179-188. https://doi.org/10.1016/j.tourman.2009.02.016 
Xiang, Z., Tussyadiah, I., \& Buhalis, D. (2015). Smart destinations: Foundations, analytics, and applications. Journal of Destination Marketing \& Management, 4, 143-144. http://doi.org/10.1016/j.jdmm.2015.07.001

Xin, S., Tribe, J., \& Chambers, D. (2013). Conceptual research in tourism. Annals of Tourism Research, 41, 66-88. http://doi.org/10.1016/j.annals.2012.12.003 